
Science Association. This is an Open Access article, distributed under the terms of the Creative Commons Attribution licence (http:// creativecommons.org/licenses/by/4.0/), which permits unrestricted re-use, distribution, and reproduction in any medium, provided the original work is properly cited.

\title{
Collaboration and Its Political Functions
}

\section{P. E. DIGESER University of California, Santa Barbara, United States}

$W$ hat functions does "collaboration" play in our moral and political practices and how did it come to play those roles? We use the term "collaboration" to identify a valued partnership, but it also names a morally compromised association and functions as a reason for blaming and punishing complicitous behavior. However, it has also played nefarious political roles: shoring up patriarchy, legitimizing ethnic cleansing, and bolstering a myth of national unity. "Collaboration" plays various roles because it is both ambiguous and vague. It is ambiguous in that there are multiple conceptions of collaboration, and it is vague because it contains borderline cases that are difficult, even impossible, to resolve. An exploration of "collaboration" combined with the history of its coming of age shows why its study is so vexing and how it functions in unexpected and disturbing ways.

$\mathbf{F}$ or most organizations, "collaboration" is a productive, if not prized activity that administrators, managers, and granting agencies endlessly (or, so it seems in academia) encourage. Moreover, we frequently use the term "collaboration" in innocuous ways to talk about cooperation, teamwork, or a group effort. But this concept has a darker side. Since the middle of the twentieth century, the word "collaboration" has captured a particularly heinous form of moral and political complicity, describing, for example, those who have aided or abetted an abusive regime, betrayed their community, or served as accessories in perpetrating genocide. Fully emerging during World War II in the context of Vichy's response to the German defeat and occupation of France, collaboration has also been used after the collapse of the Soviet Union (Czarnota 2009, 324; David 2003, 418; Horne 2009, 352; Killingsworth 2010, 82; Misztal 1999, 44; Szczerbiak 2016, 435), in the conflict between Israel and Palestine (Cohen 2012; Dudai and Cohen 2007; Peteet 1999, 81-2; Rigby 2001, 154-61; Sa'di 2005), in postwar Sri Lanka (Satkunanathan 2016), in the struggles of the Kurds (Kaczorowski 2018, 159), and in the fall of ISIS (Revkin 2018). ${ }^{1}$ Collaboration is "as black as ink and heavy as lead" (Burrin 1996, 4).

Given the concept's weight in our moral arsenal, it is incumbent on us to understand what it means particularly if we are entering a moment in which questions of political and moral complicity could acquire a certain urgency. At first glance, such an understanding appears to be close at hand: collaboration is part of our language of moral responsibility and serves as a reason for

P. E. Digeser (1D, Professor, Department of Political Science, University of California, Santa Barbara, United States, digeser@ucsb.edu.

Received: September 19, 2020; revised: March 09, 2021; accepted: June 22, 2021. First published online: August 06, 2021.

\footnotetext{
${ }^{1}$ For more recent uses, see Anne Applebaum's discussion of collaboration as it relates to individuals surrounding former President Trump (2020). Regarding these supporters, Michael Steele, a former chairperson of the Republican Party, tweeted, "The collaborators have to explain themselves. Not the resisters"(@MichaelSteele, August 25, 2020).
}

blaming and punishing those who have had a particular kind of association with a perpetrator. On this account, collaboration's primary function seems to be the identification of a form of complicity in which the collaborator is a secondary player.

Despite this clarity of function, significant disagreements exist among scholars and practitioners over what exactly counts as collaboration. ${ }^{2}$ Similarly, legal thinkers, historians, and courts have struggled over its definition. ${ }^{3}$ Moreover, in addition to identifying and attributing moral responsibility, "collaboration" has been used, paradoxically, to enact wrongs and deflect moral responsibility: it has been employed as a pretext for ethnic cleansing, as a way to enforce patriarchal norms, and as an aid in securing a myth of national unity. Obviously, any term can be twisted and misused. On the other hand, the numbers, significance, and consistency of abuses of collaboration call for closer attention. For example, since the Second World War, very few men have been blamed for sexual collaboration, while thousands of women have been so accused. Moreover, if collaboration is about wrongful activity, why did accusations of collaboration became so easily entangled in the forced removal of thousands of individuals in Eastern Europe? How can collaboration be about who one is and not what one has done? What's up with "collaboration?"

To begin to address these questions, the first half of the article discusses some broad characteristics of the concept. Philosophers have considered collaboration's relationship to complicity (Lepora and Goodin 2013) and to betrayal (Margalit 2017, 197-220), whether collaboration is ever acceptable (Kamm 2000; 2012),

\footnotetext{
${ }^{2}$ Compare, for example, understandings of collaboration offered by Armstrong 1968, 396; Dethlefsen 1990, 198-9; Gross 2000, 24-5; Hickman 2017, 228; Hoffmann 1968, 376; Kocher, Lawrence, and Monteiro 2018, 126; Margalit 2017, 206; Rings 1982, 73-152; WeissWendt and Üngör 2011, 405-10.

${ }^{3}$ See Deák $(2000,10)$ for a discussion of this problem after the Second World War, Stauber $(2011,2)$ for its problematic application to the Holocaust in Eastern Europe, and David (2003, 418) for its challenges in the context of the lustration process after the Soviet Union's collapse.
} 
and how we should respond to collaborators (Mihai 2019). What has not received philosophical attention is the possibility and significance of collaboration's being both ambiguous and vague. In the account that follows, collaboration is ambiguous in that there are at least three conceptions of collaboration, and it is vague in the sense that collaboration contains borderline cases that are difficult, if not impossible to resolve. As we shall see, both of these features matter for the uses (and abuses) of "collaboration." Grasping collaboration's ambiguity and vagueness also sheds light on why historians, social scientists, and others cannot overcome the problem of fully nailing down the meaning of the term in addition to why the study of collaboration (from a historical or social scientific perspective) requires an acknowledgement of the positionality of the researcher.

The second half offers an account of how "collaboration" acquired this ambiguous, vague shape. The historical literature on collaboration-particularly for the period of World War II-is vast. Paradoxically, historians of political thought have ignored it. Looking to the history of the concept of collaboration tells us why the unfavorable conception has the features it does, how it was used to deflect Vichy's responsibility, and then how it was abused to secure patriarchy and justify ethnic cleansing. In the broadest sense, this history is a story of how a concept became a reason for action that subsequently proliferated in unexpected and troubling ways. Finally, it is a great illustration of what historians of political thought have argued since the middle of the last century: we cannot understand our political ideas without understanding their context. $^{4}$

What is at stake in the elucidation of "collaboration?" If one believes that one's language is much more than a set of arbitrary markers randomly attached to objects or impressions but actually mediates human experience, then we cannot understand the world in an immediate, nonlinguistic fashion. Associated with this, now familiar, hallmark of interpretivism are such claims that the meaning of our concepts is in their use (and the purposes that they serve) (Wittgenstein 1958, §43), that in order to understand similarities and differences in our concepts we must "look and see" (Wittgenstein 1958, §66), and that our concepts have a time and place. From this perspective, our social world is, in part, "linguistically built up" (Schaffer 2016, xiii).

To command a clear view or (more realistically) a clearer view of "collaboration" is both to understand something about how our language shapes our world and how it serves as a resource for motivating and justifying human action. There exists a significant cor-

\footnotetext{
${ }^{4}$ Contra the suggestion by Bertram M. Gordon and others that collaborators and collaboration have always existed, even if the words themselves emerged at a particular moment (Gordon 1993, 2-3). In response to the idea of a concept avant la lettre, Frederic Schaffer argues that it may lead to anachronistic readings or a failure to recognize other interpretations of what was going on (Schaffer 2016, 67).
}

ner of our moral and political practices of responsibility that is constituted by the language of collaboration. To apprehend the functions of collaboration and how they were acquired is to understand how the concept contributes to those practices in the way it does and how it can exceed, and sometimes violate, them in disturbing ways.

\section{AMBIGUITY}

How do we know that there are multiple conceptions of collaboration? One test for ambiguity is that a sentence such as "Able collaborated with some of the finest librettists in Europe as well as in the genocide" seems to be zeugmatic. That is, even though the word "collaborated" is used only once in the sentence, it has two different senses (Sennet 2021). To flag these differences, the first, the favorable conception of collaboration, will be identified as "collaboration ${ }_{1}$ " (since it came first historically) and the second, the unfavorable conception, "collaboration ${ }_{2}$." There is also a more neutral conception of collaboration ("collaboration 3 "), which plays a minor role in this story. "Collaboration" sans subscript will refer to the concept of collaboration, which can be defined by the role that these conceptions share in identifying a kind of co-laboring.

Unlike the word "democracy," which has numerous contested meanings, the conceptual ambiguity associated with collaboration is relatively mild: restricted to the three conceptions. Like "democracy," however, this ambiguity matters both politically and for those who are trying to study collaboration. In particular, it is especially important to reiterate the significant moral weight attached to collaboration ${ }_{2}$. To accuse someone of being a collaborator ${ }_{2}$ is already to make a condemnatory judgement. In this regard, collaboration ${ }_{2}$ is much like "massacre," "genocide," "murder," and "betrayal" insofar as the descriptive and evaluative elements are utterly entangled. To say that "this is a massacre," is not a value-free assessment, independent of our judgements about the context of the killings. Consequently, when studying the idea of collaboration 2 during an occupation, it will matter whether the occupation is just. In other cases, it will matter whether the actions taken violate human rights. As I shall argue, in both cases it will also matter whether the participants to these actions are accessories or coperpetrators - that is, whether they are secondary players or plan makers. For example, at the conceptual level, it is one thing to study individuals working with American authorities in Iraq if they are collaborators 2 (in the unfavorable sense) and another phenomenon if one sees them as collaborators 1 (in the favorable sense). To make that distinction requires assessing the relationship between those with power and the collaborators as well as a moral judgement about the context, which raises the issue of positionality.

The issue of positionality will recur in the discussion of vagueness. Suffice it to say, positionality entails the researcher having to make a moral or ethical judgement in order to proceed with their work. The heart of 
the problem is that a factual instance of collaboration 2 cannot be identified without making a value judgement. The ambiguity of the concept, however, suggests different ways to more or less successfully evade the issue of positionality-namely, by focusing on the ambiguous concept and not on one of the conceptions. In some ways, this first strategy is similar to studying killings in a community without attending to whether they were wrongful, accidental, or justified. One could imagine instances in which such a study would be useful. Alternatively, one may turn to other sources (e.g., court decisions, the weight of historical evidence, or "the common opinion of mankind") to identify whether a particular instance was collaboration 2 . Finally, researchers could draw on the more or less neutral conception of collaboration ${ }_{3}$ and study people "working together." The problem with collaboration ${ }_{3}$, however, is that it may create confusion given the existence of the favorable and unfavorable conceptions. Thus, if one wants to study "working together" in an environment in which collaboration ${ }_{2}$ could be an issue, one may want to avoid the word "collaboration 3 " altogether.

\section{VAGUENESS}

"Vagueness" refers to the presence of borderline cases (Sorensen 2018) or, in the case of collaboration, the absence of a bright line that identifies when a contribution to a given endeavor becomes a collaborative effort (which can be called, "the threshold problem"). The concept of collaboration is ambiguous and each conception of collaboration (the favorable and the unfavorable) is vague. The historical claim that I will make is that the vagueness of the unfavorable conception (collaboration ${ }_{2}$ ) carried over from the favorable conception (collaboration ${ }_{1}$ ). The conceptual argument is that vagueness greatly matters to both of these conceptions (collaboration ${ }_{1}$ and collaboration $_{2}$ ). How so? With respect to the favorable conception (collaboration $_{1}$ ), it means that in most cases of artistic, literary, scientific, and administrative collaboration ${ }_{1}$ the parties have a pretty good sense of who needs to do what in order to be recognized as a collaborator ${ }_{1}$. However, sometimes one party believes that their contribution should be recognized as part of a collaborative effort (say in a scientific experiment or literary project), whereas another party sees the contribution as insufficient for such recognition. If collaboration ${ }_{1}$ generates "absolute borderline cases," then these situations resist all further empirical or conceptual inquiry (Sorensen 2018): knowing more simply does not resolve the situation.

Finding oneself at a borderline use of collaboration ${ }_{1}$ does not prevent assertations or denials of collaboration. In fact, it is all too likely to generate such assertations and denials. In the case of collaboration ${ }_{1}$, a threshold problem may lead the parties to an authoritative entity (deans, courts, mediators) to decide the issue. Or, previous experience with such disputes may lead potential collaborators ${ }_{1}$ to define explicitly what kind of contribution each must make in order to be recognized as a collaborator ${ }_{1}$. Finally, over time, vagueness may diminish in certain domains of activity through social norms that identify only certain actors as collaborators ${ }_{1}$. Throughout the arts and sciences, for example, practices associated with notions such as "author," "investigator," and "artist" hive off certain contributions from the language of "collaborator ${ }_{1}$ " (e.g., compositors, grants officers, and canvas stretchers are not usually recognized as collaborators ${ }_{1}$ ). If the problem is vagueness, however, then resolutions will always have an arbitrary quality to them: they could have plausibly been decided some other way.

As with collaboration ${ }_{1}$, the unfavorable conception's $\left(\right.$ collaboration $\left._{2}\right)$ vagueness does not mean that all of our judgements are uncertain. Those who took direct orders from a perpetrator, informed on their friends, betrayed individuals who were hiding from génocidaires, were economically entangled in the production of the enemy's materiel, or those whose writings or speeches supported crimes against humanity are central cases of collaboration 2 . In these examples, the individuals significantly contributed to and acted on the behalf of perpetrators of wrongful endeavors. They are morally complicit. The fact that vagueness does not apply to all uses of collaboration ${ }_{2}$ is good news for those who want to avoid it and for those who want to study it.

Not surprisingly, the vagueness of collaboration ${ }_{2}$ has a very different feel to it than what is encountered in a favorable case of collaboration ${ }_{1}$. For one thing, individuals usually welcome being identified as collaborators $_{1}$ but want to avoid being labeled collaborators 2 . Moreover, in contrast to collaboration ${ }_{1}$, the borderline in collaboration ${ }_{2}$ is the point at which an innocent contribution becomes a moral wrong. As disruptive as disputes can be over the favorable conception of collaboration $_{1}$, uncertainty over collaboration ${ }_{2}$ can be a matter of life or death: Is saluting collaboration ${ }_{2}$ ? Hanging a flag? Accepting employment? Having sex with the enemy? Reporting a crime? Negotiating for more rations? Keeping one's head down? Adopting a wait-and-see attitude?

Like the favorable conception, finding oneself at a borderline use does not prevent assertions or denials of collaboration $_{2}$. Unlike collaboration ${ }_{1}$, the fear that such accusations will be made can be significant and increase in the knowledge that perpetrators and resisters have an interest in manipulating the uncertainties associated with borderline cases. For perpetrators, the inexact point where an innocent contribution becomes collaboration $_{2}$ is an opportunity to stipulate the innocence of a given act of cooperation (e.g., after all, everyone has a responsibility to report crimes). Alternatively, uncertainty itself can support a "mechanism of incrementalism" (Gross 2000, 29) in which, if one step is not collaboration ${ }_{2}$, then neither is the next step down. For resisters, the pressure for moral clarity in the light of uncertainty pushes the discourse in the other direction, perhaps even to the point where resistance is seen as the only alternative to collaboration ${ }_{2}$. In these cases, the interests of the parties drive the location of the threshold, moving it in order to advance their goals. 
Unlike collaboration ${ }_{1}$, the remedies to borderline cases are absent at the point when decisions must be made that could result in an accusation of collaboration $_{2}$. There is no process that can settle such questions beforehand: Perpetrators (or resisters) and potential collaborators 2 do not get together to establish whether a potential contribution is an act of collaboration $_{2}$. Foreign occupations and ongoing genocides are difficult occasions in which to develop social norms that differentiate borderline cases. Moreover, once accusations of collaboration ${ }_{2}$ have been made, wide variation exists across and within states over how they are handled. For example, in postwar Europe, "the courts struggled with a definition of collaboration. Since no consensus existed, every national assembly, in fact nearly every court, arrived at its own definition" (Deák 2000,10). Within a given nation, the treatment of alleged collaborators seems to have depended on the collaborator's social position, how soon after liberation punishment occurred (the desire for revenge was strongest immediately after liberation), changes in the international environment, and the political goals of the new regime. In addition, accusations of collaboration ${ }_{2}$ were entangled in formal, legal charges of treason and war crimes, but also in charges of threatening national security, crimes against humanity, crimes "against the people," "national unworthiness" (Virgili 2002, 10), and being a "socially dangerous" person (Voisin 2018, 260). Bearing in mind the messiness of capturing the ways in which collaboration ${ }_{2}$ was formally handled, a sense of the degree of variation can be found in the cases of Norway and South Korea. The former tried nearly $4 \%$ of its population and sent 17,000 Norwegians to prison for treason (Deák 2015, 204), whereas in South Korea, "38 cases were effectively referred to court" (De Ceuster 2001, 214). In less formal settings, where due process considerations played little to no role, many accused of collaboration ${ }_{2}$ were forced to move (e.g., Hungarians in Czechoslovakia), shunned and shamed (e.g., collaboration horizontale), or summarily executed $(10,000$ such cases in France alone [Rigby 2001, 25]). None of this history provides much assurance that borderline cases will be fairly addressed after the fact.

What does vagueness mean for those studying collaboration $_{2}$ ? The not-so-good news is that besides the problem of positionality raised by ambiguity, scholars must also attend to the vagueness of collaboration ${ }_{2}$ The term is not precise and to render it precise is, in an important sense, to alter the object of study. Moreover, collaboration $_{2}$ carries with it a weighty moral judgment, so how one deals with borderline cases is ethically significant. Nevertheless, there are at least two general ways to mitigate the problem of collaboration 2 's vagueness: focus on easily identifiable cases or argue that there is a way that we should understand collaboration 2 such that it significantly diminishes the threshold problem.

The first approach can be seen in the work of historians and social scientists who offer a clear and distinct definition of collaboration 2 . For example, Henrik Dethlefsen argued for a "political conception" of collaboration $_{2}$ in which the focus is on political decision makers who act "under the pressure produced by the presence of an occupying power" (Dethlefsen 1990, 199). In contrast, John Hickman defined collaboration as "the decision by a citizen of a conquered state or previously autonomous entity, such as a tribe, to voluntarily accept a public office in a subordinate government established by an occupying power" (2017, 228). Stanley Hoffmann used the term "collaborationism" to refer to those in Vichy who were ideologically motivated to work with Germany (Hoffmann 1968, 376).

One advantage of focusing on clear cases of collaboration $_{2}$ is that it accords with the methodological impulse to operationalize concepts in a way that mitigates ambiguity and vagueness. Each of the above definitions focuses on tractable, central cases of collaboration $_{2}$. A second advantage is that focusing on central cases can accord with a moral impulse that sees including hard, vague cases into a scholarly study of collaboration $_{2}$ as troubling or unfair. For example, Phillippe Burrin argues that it is "unsuitable" to apply "collaboration" to ordinary individuals whose "sole preoccupation" was just to get through the situation in Vichy (1996, viii). Given the circumstances they faced-"a partially confused image of the occupier, an opaque future, disagreement as to the correct definition of the national interest, and the burdensome business of securing the necessities of life"-it is better to use words like "adaption" and "accommodation" to describe their actions instead of collaboration $_{2}$. For Burrin, collaboration 2 , identifies a "politico-ideological perspective" that sought entente with the Germans (1996, viii).

One challenge of operationalizing or defining vagueness out of the study of collaboration ${ }_{2}$ is that the more one narrows the conception of collaboration ${ }_{2}$ to clarify it, the more one is likely to exclude other clear cases of collaboration $_{2}$. For example, by focusing on the context of foreign occupation, all of these definitions exclude clear cases of collaborating 2 in, say, civil wars or in the violation of human rights outside that context (WeissWendt and Üngör 2011, 406). Moreover, by focusing on clear cases of collaboration 2 in the political realm, they exclude clear cases such as economic collaboration ${ }_{2}$ by businesses. But putting those issues to the side, even as clear as the definition offered by Hickman and Dethlefsen may be, their understandings raise questions of how to deal with what Werner Rings called "tactical collaboration" $(1982,128)$. Should instances in which administrators are simultaneously collaborating and resisting with an occupying power be seen as collaboration $_{2}$, excused collaboration ${ }_{2}$, or as borderline cases? Similarly, are public officials in a subordinate government who provide essential services supporting both occupied and occupiers (e.g., water, electricity, heat,

\footnotetext{
${ }^{5}$ Kocher, Lawrence, and Monteiro define collaboration as "the active pursuit of objectives shared by the occupied and the occupier or even driven by the occupied under the protection of the occupier" $(2018,126)$. This definition employs (correctly, in my view) the notion of collaboration ${ }_{1}$ as it was initially used by Vichy. However, collaboration $_{1}$ is not the only conceptual game in town.
} 
medical care) collaborating 2 because of their official position or do their activities fall into a liminal space? Even if one acknowledges the provisionality of any operationalization/definition of collaboration $_{2}$, the problem of vagueness may not disappear. Thus, the difficulties that scholars have had in trying to nail it down.

Alternatively, one could argue that there is some better way to understand collaboration ${ }_{2}$ that is not vague and is not subject to the sorts of abuses mentioned in the introduction. One could construct an ideal conception of collaboration ${ }_{2}$ that is most compatible with our notions of agency, responsibility, complicity and so on. For example, Chiara Lepora and Robert Goodin (2013) argue that what I call collaboration ${ }_{2}$ is a subtype of complicity in which collaborators ${ }_{2}$ are not "coprincipals." Moreover, they claim that complicity entails agents making "potentially causal contributions to the principal wrongdoing of others, without their acts in any way constituting part of that principal wrongdoing in themselves" $(2013,41)$. Collaboration ${ }_{2}$, then, is a specific kind of wrongdoing. Those who are complicit are accessories and hence collaborators ${ }_{2}$ are not leaders. As followers, they take instructions from a "plan" and adjust their "own actions to it" $(2013,43)$. Collaborators 2 may even be equivocal about adopting the plan, but they are plan takers and not plan makers (2013, 71-2).

Given the vagueness of collaboration ${ }_{2}$ and its moral weight, normative accounts such as that provided by Lepora and Goodin (2013) can help address the threshold problem and the abuses noted earlier. Their account tells us that if individuals are not acting as plan takers for a perpetrator, as in the case of many women accused of collaboration horizontale, then we should not call them "collaborators 2 . Most of these women were not plan takers, and their actions did not have much effect on perpetuating the occupation or on Germany's ability to wage war. On the other hand, French bureaucrats who took orders from the Germans and kept the electricity on and the water running in Paris performed actions that were necessary to maintain Germany's unjust occupation. Consequently, under Lepora and Goodin's account they would probably be labeled as collaborators 2 .

If a normative conception of collaboration ${ }_{2}$ could mitigate or eliminate vagueness, then it would seem to be a great improvement over our present situation. However, as was true of operationalizing-away borderline cases, a normative ideal of collaboration ${ }_{2}$ that could always and correctly identify the point at which an innocent contribution became collaboration ${ }_{2}$ would be an altered conception of collaboration ${ }_{2}$. But so what? Given the stakes involved for those who must act under foreign occupation or in the midst of massive violations of human rights, the value of altering the meaning of collaboration $_{2}$ to make it clearer is obvious. For scholars, approaching the study of collaboration ${ }_{2}$ through a normative lens such alteration would merely require, once again, admitting positionality into one's researchnamely, narrowing the term to what is normatively justifiable. However plausible such a project of conceptual reform and adoption may be (and assuming we have arrived at a reasonable conception of how collaboration 2 should be understood), it should not blind us to the fact that until that transformation occurs we are stuck with a conception of collaboration ${ }_{2}$ that is vague. To be accused of collaboration ${ }_{2}$ is no small thing, and the history of the term suggests that those who are liable to such accusations is shockingly broad. To understand how and why collaboration $_{2}$ functions as it does, we must turn to its history. That history will offer an account of how collaboration came to be ambiguous and why collaboration ${ }_{2}$ is vague and so subject to abuse.

\section{THE BIRTH OF COLLABORATION 2}

To understand collaboration ${ }_{2}$ and its political functions, it is important to understand its relationship to collaboration $_{1}$. Prior to the Second World War, the French and English meanings of "collaboration" are very much connected to "Working with others, especially in literary, scientific or administrative areas" although in French it also possessed a more specialized legal meaning associated with the common concerns of husband and wife (Dictionnaire de l'Académie française, 8th edition, 1932-5, https://vlf.uchicago. edu/mot/collaboration). While collaboration's neutral connotation may be connected to the innocent idea of "working with others," the dictionary examples suggest work that is commonly valued if not valuable. The positive possibilities of collaboration are most easily seen in the arts and sciences, where its use was fairly common before to the war. In the case of its application to administrative work, collaboration ${ }_{3}$ may be more frequently used, but it is not difficult to find prewar examples where it is used in a positive way (Estève 1938, 8-11).

Complicating matters is the fact that in its prewar usage, one could judge a particular instance of collaboration $_{1}$ as unfavorable despite its overall favorable connotation, just as one could value the idea of friendship but still find a particular friendship troubling. For example, in Henry James's 1892 novella Collaboration (2017), the emerging partnership of a French poet (Felix) and a German musician (Herman) is viewed with disdain by others precisely because working across those particular nationalities is judged to be odious. Their friends are troubled because Felix and Herman see their collaboration ${ }_{1}$ as a creative opportunity. Even before an unfavorable conception of collaboration ${ }_{2}$ had emerged, collaboration ${ }_{1}$ was pretty flexible.

Despite collaboration's rather anodyne character, the political left in the first decades of the twentieth century were able to coopt the word to express derision. In the 1910s and 20s, the Italian words collaborazionista and collaborazionismo entered the Italian political lexicon and were used to describe socialists willing to work with the liberals (Gordon 1993, 1; Panzini 1923, $134,220,700)$. To the extent that one could be accused of being a collaborazionista in early twentieth-century Italian politics, collaboration 2 seems to have made its first appearance (De Grand 1989, 31-44; Di Scala 1980; Landolfi 1996, 9-18). In 1920s England, one can see a 
similar political use of collaboration ${ }_{2}$ in the call for the Labour Party to view the Tories as their enemies and "refuse any measure at all of collaboration with them" ("When Parliament Meets" 1925, 11). In Western Europe, these may be the earliest uses of collaboration 2 , although they are only hinting at a sense in which the collaborators $_{2}$ are taking orders from the Italian Liberals or the English Tories, a feature that becomes prominent in the myth of Vichy. Still, one could ask why these cases are not more aptly described as unfavorable judgements of collaboration (say, as found in James's novella) or of collaboration ${ }_{3}$ ? The reason, in part, is that when "collaboration" is functioning as an accusation, it is odd to accuse someone of collaborating $_{1 \text { or } 3}$ simplicter. $^{6}$

In the $1920 \mathrm{~s}$ and $30 \mathrm{~s}$, collaboration 2 also appears embedded in the left's notion of "class collaboration" ("Second Letter to the I. L. P." 1926; Smith 1924; "The National Minority Conference" 1924). For example, sometimes reformist leaders were described as "the champions of class collaboration" (All-Russian Council of Trade Unions 1926, 68) and those who "follow in the footsteps of the class collaborators... are traitors to the working class..." (All-Russian Council of Trade Unions 1926, 78; See also Murphy 1934, 36, 63, $73,142,249)$. In these uses, not only does collaboration 2 appear, but it may also have been in response to calls by politicians, capitalists, and union leaders for collaboration $_{1}$ between workers and management to secure industrial peace after World War I (Amulree 1929, 149). In other words, what is a policy of cooperation between workers and management for some is easily turned into a symbol of betrayal for others. All ideas have legs. It is possible that collaboration ${ }_{2}$ migrated from Italy into France and England and was sustained by its use in socialist critiques of any suggestion of industrial peace after the Great War. The leftist composition of the French resistance (Kocher, Lawrence, and Monteiro 2018, 146) may be further evidence of this connection, although it is also likely that collaboration's use in the context of Vichy was overdetermined.

Within this broad conceptual context, "collaboration" was swept into the events of 1940. In the June 22, 1940 Armistice Agreement ending hostilities between France and Germany, collaboration played a role in defining the Franco-German relationship. Article III of the Agreement called for French administrative services to collaborate with the German military authorities in a correct manner ("Convention d'armistice" 1940). For the authors and signatories of the armistice, the goal was to prevent further bloodshed and secure peace and order. France promised that its bureaucracy would stay at its post, fulfill its duties, and work with the Germans.

One can certainly read the use of "collaboration" in the Armistice as the neutral conception of "working with" the Germans. However, less than a month later,

\footnotetext{
${ }^{6}$ Nevertheless, it would be too strong to claim that one can be accused of collaboration only if it is collaboration ${ }_{2}$. For example one could be accused of collaboration ${ }_{1 \text { or } 3}$ if, say, a homework assignment was meant to be done without the help of others.
}

on July 10, 1940, what looks like collaboration appears $_{1}$ in what was called the "Bergery Declaration." Penned by the French jurist Gaston Bergery and submitted to the National Assembly, the Declaration argued that collaboration with Germany was preferable to the government's withdrawing to England. For Bergery (and for Pétain), such collaboration opened the possibility for "the establishment of a new continental order" (Labrosse 2008, 73). On July 26, 1940, the French Minister of Foreign Affairs, Paul Baudouin, declared in a confidential memorandum his support for a "lasting collaboration with Germany,' that would make it possible 'to create a new Europe"' (Burrin 1996, 79). A few months later, on October 31, 1940, President Marshal Pétain employed collaboration in an infamous radio address regarding Vichy's relationship to Nazi Germany. Pétain declared, "I enter into the way [or path] of collaboration" (Burrin 1996, 65; Paxton [1972] 2001, 77).

When did the unfavorable notion of collaboration $_{2}$ appear in this broader political context? The precise moment is not entirely clear, although the political response to Pétain's use of "collaboration" was almost immediate. In his December 20,1940 speech, "What the Enemy Means by Collaboration," Charles De Gaulle proclaimed, that "France's 'collaboration' in the war is nothing less than the utilization of France for the war" $(1944,40)$. The presence of scare quotes around collaboration may be signaling an ironic use of the word or simply identifying Vichy's policy. A couple of months later, an unnamed author in the Free French newspaper, Notre révolution (1941) drew a parallel between the German collaborative relationship to France and the French collaborative relationship to Syria, Indochina, Tunisia, and Morocco. In other words, collaboration is a great thing as long as France is not the colony. The irony of the statement may depend on the ambiguity of the concept of collaboration ("Que signifie la collaboration?" 1941).

As suggested above, using collaboration as an accusation is a clearer indication of its unfavorable connotation. For example, on June 29, 1943, L'Echo d'Alger: journal républicain du matin reported that in "In Poitiers, notorious collaborators ... [were] executed in the middle of the street...." ("Le peuple de France ...." 1943). In October of that year, The New York Times reported that Countess Marianna von Moltke was "accused of collaborating with Grace BuchananDineen, alleged head of a Nazi spy ring" ("Countess Pleads Guilty" 1943). By 1944, references increasingly identify individuals accused, found guilty of or punished for collaboration. ${ }^{7}$ By 1945 , collaboration ${ }_{2}$ is fully deployed in both French and English and speakers could straightforwardly say such things as "there is no excuse for collaboration" about those being tried for their wartime activities (Bonitzer 1945).

\footnotetext{
${ }^{7}$ For example, see The Sphere's July 22, 1944 story, "Civilian Life in the Liberated Regimes: A Series of Pictures from Normandy after the Passing of the Germans" (118) and Combat's "Des Cours de Justice seront chargées de juger les faits de trahison ou de collaboration avec l'ennemi" (September 16, 1944).
} 


\section{COLLABORATION $_{1}$ AND VICHY}

In telling the story of collaboration, it is essential to remember that the Vichy leadership saw collaboration $_{1}$ with Nazi Germany as a necessary and, for some, a good thing. The hope was that the path of collaboration $_{1}$ led away from a "peace of oppression" (Paxton [1972] 2001, 72) and toward Vichy's recognition as a coprincipal in the creation of a new Europe. Burrin goes so far as to argue that Vichy's policy proposal implied being on an equal footing with Germany (Burrin 1996, 58-9; Kocher, Lawrence, and Monteiro 2018, 132; Lemberg 1972, 145), a point that I will address below. In light of what, in 1940, was looking like an inevitable German victory over England, Vichy sought recognition as a sovereign team player in a brave new world.

Vichy also saw collaboration ${ }_{1}$ as a way to ameliorate its wartime burdens, preserve the French empire, return the government to Paris, and engage in a National Revolution. As historians have noted, Vichy leadership took the French defeat as an opportunity to remake France (Michel 2011, 174). Paxton notes that while the advocates of a National Revolution had their own individual visions of what France should look like, they all saw its laissez-faire economy, parliamentary government, and mass society as common enemies (Paxton [1972] 2001, 142). The policy of collaboration 1 revealed the depth of the ideological divide between those seeking to restore the republic and those pinning their hopes on Vichy as the spearhead for a National Revolution (Rousso 1991, 6-7). At its heart, the National Revolution called into question the legitimacy of republican government.

From the perspectives of Vichy and Germany, what exactly did collaboration mean? $_{1}$ One can draw at least five features from Vichy's policy which comport with collaboration ${ }_{1}$ 's ordinary use in prewar discussions of the arts and sciences. First and, perhaps, foremost, collaboration $_{1}$ is not a solo operation. In the case of Vichy, this meant that France could not be a collaborator $_{1}$ unless Germany collaborated ${ }_{1}$ as well. Similarly, in the case of the arts and sciences, no one is a collaborator $_{1}$ without other collaborators 1 . Second, collaboration $_{1}$ is compatible with the partners being coprincipals - which was Vichy's aspiration. However, equality of contribution is not a necessary condition for collaboration $_{1}$. Nor must collaborators 1 be equal in ability or power. As in the arts and sciences, one party may lead and another may follow their direction without undermining the collaborative ${ }_{1}$ nature of the venture (Besant 1892, 204). Even in light of these inequalities, there still is a sense of recognition of standing, perhaps even a kind of equality of standing that is part of being a collaborator ${ }_{1}$.

\footnotetext{
${ }^{8}$ For illustrations of this kind of standing in prewar uses of collaboration $_{1}$, see Lancet's discussion of the role of nurses in "The Limits of a Surgeon's Liability," $(1924,140)$ and Matthews' discussion of literary collaboration $(1890,159)$.
}

Burrin's comment about equal footing suggests the role of recognition and equality in Vichy's use of collaboration $_{1}$. Paradoxically, it is also reflected in the German response to French overtures to collaborate ${ }_{1}$. For much of the German High Command, collaboration $_{1}$ with Vichy was viewed with disdain. The German Ambassador to France, Otto Abetz, reported "that Hitler would stammer over the word Kollaboration, finding it hard to pronounce." For Burrin, "a better clue to his [Hitler's] state of mind would be hard to find" (Burrin 1996, 95; Rings 1982, 78-9). From France, Hitler wanted "docility, loot, and perhaps bases, not cooperation among equals" (Paxton [1972] 2001, 112; see also Kocher, Lawrence, and Monteiro 2018 , 144). Collaboration ${ }_{1}$, with its implied recognition of status was anathema to much of the German leadership: "Collaboration was a French proposal that Hitler ultimately rejected" (Paxton [1972] 2001, 51). What Vichy sought and never received was full recognition as partners or true collaborators ${ }_{1}$.

Third, collaboration ${ }_{1}$ requires a meeting of minds regarding the object of their co-laboring. As noted, Vichy saw the point of collaboration ${ }_{1}$ as encouraging Germany to bring France on board with its various projects from arranging the treatment of French prisoners of war to constructing "a new Europe." Success-

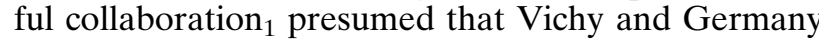
shared intentions that advantaged both parties (or so Vichy hoped). Similarly, in the arts and sciences, the failure of collaborators 1 to jointly pursue a project would be a failure of collaboration ${ }_{1} .{ }^{9}$ Such a failure may result in a party withdrawing their authorship because of disagreements over methods or conclusions.

Fourth, the Vichy case also illustrates the complicated relationship between collaboration $_{1}$ and coercion. In the case of the Armistice, the French bureaucracy could be committed to collaborate ${ }_{1}$ even though the context was one of extreme coercion. It is

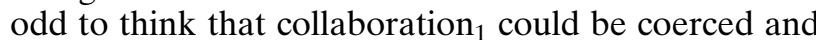
still be favorable. Still, one can imagine a situation in which the end result is valued but one of the parties is pressured or "roped into" participating. ${ }^{10}$ In Vichy's case, the context was extremely difficult. The regime pursued a policy of collaboration ${ }_{1}$ under conditions in which Germany occupied much of France (including Paris), held 1.8 million French prisoners of war, and extracted significant amounts of wealth and material goods from the country as punishment. Nevertheless, Germany did not force Vichy to adopt a policy of collaboration $_{1}$ (Kocher, Lawrence, and Monteiro 2018, 137; Scheck 2010, 384). In their efforts to collaborate $_{1}$, Vichy was no mere taker of German orders but exercised some degree of autonomy in offering possible collaborative $_{1}$ projects. For example, Paxton's work

\footnotetext{
${ }^{9}$ For the importance of "unity of impulse" in literary collaborations ${ }_{1}$, see Matthews $(1890,168)$ and Besant $(1892,202)$.

${ }^{10}$ For example, in turn-of-the-century French theater, playwrights would sometime be forced into a collaboration $n_{1}$ by a director or stage manager. The imposed collaborator was usually a family member of the director or manager. The point was to garner a portion of the playwright's royalties ("Partie non Officielle" 1906, 135).
} 
([1972] 2001; see also Rings 1982, 118) is replete with Vichy proposals to the Germans. These included the French offer to take control of British oil fields in Syria (Paxton [1972] 2001, 58-9), engage in military collaboration (125), administer the "relève" system (281-2), and round up foreign Jews (296). The larger, violent context of Vichy's situation hampered the agency of Vichy's leadership, but it was compatible with pursuing a policy of collaboration .

Fifth, collaboration ${ }_{1}$ is vague and suffers from the threshold problem. Examples appear in various accounts of prewar literary collaboration : $_{1}$ Should the adaptor of a novel into a play be recognized as a collaborator $_{1}$ with the novelist ("Court Theatre" 1872 , 442; "Dramatic Collaboration" 1871, 155; "Mr. Tom Taylor's Plays" 1871, 697)? Should not actors be recognized on playbills as collaborating with playwrights ("Dramatic Collaboration and Conveyance" 1886, 881)? Why don't people recognize that simply offering a plot or serving as an editor or just being available is not sufficient for the status of collaborator (Besant 1892, 206)?

The question of collaborative status vexed not only literature and theater but also sculpture and architecture in prewar Europe. This issue appeared before a French court in the case of Goustiaux c. Soulès concerning whether an architect who designed a sculpture's base should be recognized as a collaborator with the sculptor ("Collaboration-statue avec piédestal." 1906, 141-2). In the same year, another writer notes that the best way to avoid these difficulties is through mutual agreement and understanding ("The Architect and the Sculptor" 1906). The same will be true in discussions of scientific collaboration a century later.

One can see how the threshold problem could aid Germany's ability to string Vichy leadership along. In the fall of 1940, German negotiators signaled to Vichy the possibilities of collaboration 1 : "Hitler himself on several occasions requested help from France for particular projects, holding out the hope of thereby earning a better fate. Yet, he never committed himself as to the future in any way, and kept reciprocity for favours rendered to the strictest minimum" (Burrin 1996, 85; Rousso 1991, 251). Thus, Vichy and Germany did successfully cooperate over prisoners of war (Scheck 2010), economic coordination (Burrin 1996, 232), and the imprisonment and deportation of Jews (Gordon 1993, 13). Nevertheless, on the issues of seeing Vichy as an equal partner, repatriating large numbers of French prisoners of war, moving the capital back to Paris, eliminating French "reparations" to Germany, or guaranteeing the sanctity of the French Empire, Germany did not budge. It lured Vichy with the possibility of a mutually profitable arrangement without any intention of following through.

In this game, the French repeatedly complained about German responses, but any evidence of movement (given the threshold problem) could give hope to supporters that they were indeed on a path of collaboration $_{1}$ with Germany. It may be bumpy and not well delineated, but at least it is a path. In contrast, for the
Germans, such overtures could be framed as useful to the Reich but not indicative of a collaborative ${ }_{1}$ partnership. Until Germany dissolved Vichy and occupied the whole of France, the absence of a clear threshold triggering recognition meant that the parties could interpret their interactions as they wished. The vagaries of contribution and recognition (in part due to the vagaries of the occupier's intent [Gross 2000, 26]) kept the policy of collaboration ${ }_{1}$ alive, and the hope of

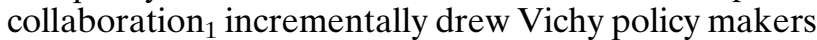
closer to Germany.

\section{COLLABORATION $_{2}$ AND THE MYTH OF VICHY}

The historical reconstruction of French collaboration with Germany during the Second World War has gone through a number of waves. ${ }^{11}$ Perhaps the most important revision involved dismantling the myth that resistance to the German occupation was widespread and generally supported. Within this myth, those who collaborated $_{2}$ were a few bad apples and their collaboration $_{2}$ did not reflect deeper divisions in French society over the legitimacy and value of republican government. That myth was useful in evading a national reckoning and securing unity. In the late 1960s and 1970s, such work as Marcel Ophuls' documentary, The Sorrow and the Pity (1969) and Robert Paxton's history, Vichy France: Old Guard New Order 19401944, first published in 1972, shattered the myth and a very different understanding of Vichy emerged.

If the historical Vichy tells us something about the central features of collaboration $_{1}$, the mythical Vichy tells us about the central features of collaboration 2 . As suggested above, the former reveals that collaboration includes a presumptively favorable character, the necessity for other collaborators 1 , the importance of recognizing a rough equality of status, the meeting of minds, the complicated role of coercion, and the existence of borderline cases. In light of these features of collaboration $_{1}$, Vichy looks much more like a failed perpetrator than a coerced accessory.

The mythical Vichy reveals a conception of collaboration $_{2}$ in which many of the features of collaboration are rendered optional. Instead of requiring multiple collaborators $_{1}$, collaboration ${ }_{2}$ could involve one collaborator $_{2}$ and one perpetrator. While collaborators ${ }_{2}$ could share the intentions of the perpetrator, they could also vociferously disagree. Completely altered in collaboration 2 was any hint of favorableness and any need for recognition in order to obtain the "status" of collaborator $_{2}$. Fully retained in collaboration 2 was its vagueness and complicated relationship to coercion. What became a new feature in collaboration ${ }_{2}$ was the "perpetrator" and the sense that collaborators ${ }_{2}$ are accessories.

\footnotetext{
${ }^{11}$ Henry Rousso, using a psychoanalytic approach (1991), charted four distinct representations of Vichy's past. For a discussion of JeanPierre Azéma's addition of a fifth phase, see Munholland 1994, 803.
} 
In the myth, Vichy's leaders were coerced, secondary players, who took orders from the Germans and never shared the dream of a new France in a new Europe. In that story, "public affairs under the occupation were a simple matter of German demand and Vichy response" (Paxton [1972] 2001, 47). Collaborators 2 took their marching orders from the Germans. Some of them acted with more enthusiasm than did others, but because they took orders from the Nazi perpetrators, they collaborated ${ }_{2}$. Finally, in that myth, resistance to the Germans was broad and deep. While true believers in the Reich and opportunists existed, they were the isolated exceptions. Jean-Paul Sartre took this stance when he wrote that, despite ultimately serving as head of the Vichy regime, Pierre Laval represented an aberration or an exception: merely an embittered loser (Sartre [1945] 2008a, 33).

What difference does it make if the story of Vichy was framed by collaboration 2 and not by collaboration $_{1}$ ? The primary effect of seeing the situation through the lens of collaboration ${ }_{2}$ is that it shifted the focus away from Vichy's attempts to secure a partnership with Germany (that is, on collaboration ${ }_{1}$ ). Moreover, for Vichy's supporters, collaboration ${ }_{2}$ also potentially excused what they had done. For if they did not share the intentions of the German perpetrators (which collaboration 2 does not require), if they had acted under enormous coercive pressure (which they could have under collaboration 2 ), and if their actions made the lives of the French people better than they would have otherwise been (which was part of the historical debate at the time), then perhaps their actions were excusable. As Pétain famously claimed at his trial, "Every day, a dagger at my throat, I struggled against the enemy's demands. History will tell all that I spared you, though my adversaries think only of reproaching me for the inevitable" (Paxton [1972] 2001, 358). He saw himself as France's shield, playing a double game with Germany, while DeGaulle was its sword. If Vichy was primarily responding to German demands (once again, as suggested by collaboration ${ }_{2}$ ), then one could see its response as a cowardly form of collaboration ${ }_{2}$, particularly if one believed that Vichy should have resisted those demands, or as excusable if one believed Pétain's story. In either case, under the cover of collaboration $_{2}$, Vichy could be counted among the victims and not as a perpetrator.

Collaboration $_{2}$ also helped to conceal the depth of the ideological differences represented by the Vichy regime. It hid what writers have called the guerre franco-française (Hoffmann 1968, 381; Rousso 1991, $21)$. From the perspective of the attempted collaboration $_{1}$, the difference between those who sought to transform France through its defeat at the hands of the Germans and those who sought to restore the republic by resisting the Nazis was broad and maybe even unbridgeable. In contrast, under the myth, Vichy may have had its share of true believers and fascists, but of course, one need not share the intentions of the perpetrators to collaborate 2 nor do one's actions need to be voluntary (Lemberg 1972, 154). If the Germans, not the French, were the plan makers, then the divide between who did and did not collaborate 2 had nothing to do with a National Revolution. For the supporters of Vichy, the difference could be framed as one between those who chose to resist the Nazis and those who got their hands dirty by remaining in office and shielding the country from the horrors of occupation. And the National Revolution? In the narrative that dominated the 20 or so years of French history after the war, "Petain's National Revolution became no more than a conservative critique of the Third Republic, an advocacy for more [nationalist, monarchic, Catholic] Maurassian authority and discipline in French political life, and a return to certain moral values" (Munholland 1994, 804). The split between Vichy's supporters and the Gaullists was great, but under the story of collaboration ${ }_{2}$ it need not be framed as a fundamental question of French political identity. Collaboration ${ }_{2}$, from its beginning, paradoxically functioned to secure national identity and diminish moral responsibility.

It is difficult to ignore the degree to which the lens of collaboration $_{2}$ aligned with the narratives of those who sought to defend Vichy as well as the Gaullists who sought to cultivate postwar national reconciliation. To be clear, the claim is not that collaboration 2 was consciously devised as a way to conceal the depth of Vichy's guilt, but that the ambiguous character of collaboration turned out to be an unexpected resource for significant political interests. And, it is within this mythical construction that collaboration ${ }_{2}$ came of age, acquired its character, and established itself as a judgment of complicity.

\section{COLLABORATION ${ }_{2}$ : SECURING PATRIARCHY AND JUSTIFYING ETHNIC CLEANSING}

Collaboration ${ }_{1}$ 's vagueness allowed France and Germany to see what they wanted to see in their relationship. Collaboration's ambiguity played an unexpected role in constructing the myth of Vichy, but it may be also fair to say that the myth of Vichy aided in the construction of collaboration ${ }_{2}$. We can now turn to ways in which collaboration,'s vagueness has enabled political uses and abuses that go beyond the idea that collaborators $_{2}$ must co-labor with a perpetrator. Consider, for example, how collaboration ${ }_{2}$ has been gendered and sexualized in addition to being deployed against ethnic groups. As is well known, in postwar France, Belgium, Italy, Norway, and the Netherlands, tens of thousands of women had their heads shaved for collaborating $_{2}$ with the Germans. In many of these instances, these women had contributed to the German project by providing political or military support, denouncing someone, engaging in black market activities, or belonging to an Axis country (Virgili 2002, 12; see also Simonin 2009, 3-6). In France, however, the basis for at least half of these cases was that they had "a relationship" with the enemy (Virgili 2002, 15). Not all of the women who were accused of having a relationship, had a sexual relationship: some met Germans socially in groups, and some interacted with Germans 
because of their work (Virgili 2002,23). Ultimately, the phrase "collaboration horizontale" became common in France even though it concealed the complexity of these relationships (Virgili 2002, 15).

A similar phenomenon, occurring in a very different historical and cultural context, appeared during the First Intifada. In some instances, Palestinian women were accused of collaboration ${ }_{2}$ not because they had co-labored with Israelis but because they had engaged in "immoral" behavior and thereby undermined the national struggle (Rigby 2001, 156). In addition to sex workers and adulterers, pornographers, drug dealers, and homosexuals all became liable to the accusation of collaboration $_{2}$ (Dudai and Cohen 2007, 44; Rigby 2001, 156). In the extreme, "Women killed as collaborators were usually deemed to have been prostitutes" (Peteet 1999, 82). According to Andrew Rigby, during this time, "any woman who appeared to step beyond the narrow bounds of appropriate conduct within Palestinian society risked being denounced as a security threat or collaborator" (Rigby 2001, 156).

Just as puzzling, one's liability to being accused of collaboration $_{2}$ may also be structured along lines of sexuality. Jean Paul Sartre's essay, "What is a Collaborator?" sexualizes the collaborator 2 (who he sees as a permanent enemy within all democracies). He writes, "It seems to me there is a strange mixture of masochism and homosexuality here. And Parisian homosexual circles provided many a brilliant recruit" (Sartre [1945] 2008b, 60; Treat 2012, 83). For Sartre, true manliness is to be found in those brave individuals who fought out of principle and said "no" to the fact of the French defeat.

Collaboration $_{2}$ has also made an appearance as a reason for ethnic cleansing. For example, the historical memory of Stalin's forced removal of tens of thousands of Crimean Tatars, Kalmyks, Karachaevs, Chechens, and Ingushes is frequently framed in terms of a false accusation of mass collaboration 2 . As many writers note, these nationalities were accused of "collaboration with the Germans [and] ... deported to Central Asia, Siberia and the Arctic north" (Dostál and Knippenberg 1992, 632). It is more likely, however, that Stalin's accusation against these people was that of "mass treason" (Williams 2002, 340). Nevertheless, collaboration $_{2}$ explicitly enters when the Soviet Union "rehabilitated" the Crimean Tatars in 1967: they noted that the "accusations of the active collaboration of a section of the Tatars resident in the Crimea with the German usurpers were groundlessly leveled at the whole Tatar population of the Crimea" (Fisher 1978, 179). In effect, while there were instances of individuals who worked for and with the Nazis, thousands of individuals had been deemed collaborators 2 because of who they were and not because of anything they had done.

One way to approach the puzzle of gendered and sexualized collaboration ${ }_{2}$ is through the ways in which territoriality is imbricated with patriarchy and heteronormativity. Regarding patriarchy, Fabrice Virgili and others have argued that the bodies of women are "symbolically interchangeable with the nation"
(Virgili 2002, 241). Within this symbolic association, a woman who has consensual sexual relations has traitorously surrendered national territory and so in the French case, collaboration 2 represented the "absolute defeat of France" (Virgili, 2002, 239). Along similar lines, Kjersti Ericsson argues that, “women's sexuality as national property is central to the framing of both war rapes and consensual sexual relations with enemy soldiers" (Ericsson 2010, 68). Head shaving, according to Virgili, became a rite of purification in which those bodies were reconquered.

If we take Virgili and Ericsson's explanation as given, why did collaboration ${ }_{2}$ (as opposed to some other word) serve as a reason for action in these contexts? Part of the answer is provided by Rigby's comment that "immoral" Palestinians (both women and others) were seen as undermining the national cause. Although they were not directly aiding the Israelis, they were indirectly doing so (it is suggested) by weakening the Palestinian community. A similar view can be found in Venessa Voisin's discussion of how Soviet authorities understood sexual collaboration 2 with Germans. In their eyes, "this kind of collaboration precisely denied every interpersonal code and practice prevailing in the invaded community; it therefore represented a major threat to the cohesion and survival of the community" (Voisin 2018, 248; see also Jones 2005, 762-4). From this perspective, the question of whether having a drink, sex, or being a homosexual directly helps the enemy is beside the point in discerning collaboration ${ }_{2}$. Rather, it is enough if socializing with the enemy or having a particular identity is perceived as harming the oppressed community. How is all of this connected to collaboration $_{2}$ 's vagueness?

To recall, the threshold problem entails the difficulty of identifying when an innocent contribution becomes a moral wrong. In cases of foreign occupation, a contribution is ordinarily understood as that which aids the enemy. It is more than likely for those suffering under such domination to see a connection between what aids the enemy and what harms one's community. In other words, contributions that help the enemy must be harming one's own group or nation. If the meaning of collaboration $_{2}$ 's notion of contribution is vague, however, then harming one's community could be seen as aiding the enemy. With this reversal, the central ques-

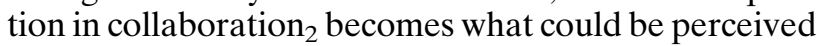
as harm to the community. Very generally, the answer is quite broad, stretching from material deprivation, to misrecognition, to the erosion of norms and values believed to be central to the community's life, to the mere presence of difference, none of which need include taking orders from the enemy.

In this logic, collaboration 2 's threshold problem is transformed from trying to identify when an innocent contribution becomes a moral wrong to trying to determine when harming the community becomes a matter of helping the enemy. Just as the threshold problem can open a political opportunity for perpetrators and resisters to assert their own interpretation of borderline cases, "defenders" of a community may assert their preferred version of what weakens the community. 
Collaboration $_{2}$ now becomes a reason for acting against any threat to the community, even if no plans with the enemy have been exchanged. Those who deploy this use of collaboration 2 as a reason for action see themselves as guardians of a particular vision of their community and defending it against internal and external threats who are now linked together.

On this reading, if patriarchal norms that regulate with whom French women should appear, work, or have sex are part and parcel of the community's identity and if women associating with German men is a threat to those norms (and that communal identity), then collaboration horizontale becomes a reason for punishing women who violated those norms. Similarly, if the heteronormativity of mid-twentieth French society meant that homosexuals were seen as a threat to that community, then their very existence weakens the community. If homosexuality is seen as weakening French society, then it should not be surprising that they, as a group, came to mind for Sartre in his discussion of what is a collaborator. Similarly, if homosexuality, adultery, or "immoral female behavior" were perceived as a threat to Palestinian society or certain ethnic groups were seen as a threat to Soviet identity, then they too could be framed as collaborators 2 even in the absence of any co-laboring with the Israelis in one case or with the Nazis in the other. Collaboration ${ }_{2}$ with its attendant threshold problem can enable a logic in which "what harms us helps the enemy" plus a hefty sense of moral condemnation. The claim is not that collaboration $_{2}$ creates those biases and perceptions of threat but that the structure of the conception can forge a connection between them and a perceived enemy. Once those connections are in place, existence itself may be seen as a contribution to an enemy's cause.

The emergence of collaboration ${ }_{2}$ was neither inevitable nor necessary. Nor is it necessary that we continue to use it as we do. As Wittgenstein noted, language is not a cage (Schaffer 2016, 96). It is possible that the overwhelmingly favorable use of collaboration ${ }_{1}$ that litters contemporary life may ultimately swamp collaboration $_{2}$, turning the latter into an archaic expression devoid of function. Alternatively, we may develop practices that delineate innocent contributions from collaboration $_{2}$. Similarly, within the context of unjust foreign occupations, we may come to adopt the kind of humane solution offered by Burrin (1996), which restricts collaboration ${ }_{2}$ only to those who are seeking an entente with a perpetrator. Finally, authoritative institutions, such as courts and commissions, could incorporate the sort of normative solution offered by Lepora and Goodin (2013), clarifying the idea of collaboration $_{2}$ and mitigating the threshold problem.

On the other hand, there are reasons not to be so sanguine about these possibilities. As noted earlier, even though things look very different in a borderline case depending on whether one is at the point of decision or after the fact, neither situation inspires much confidence. Moreover, the possibility that vagueness can serve the interests of perpetrators and resisters as well as fuel the abuses noted above adds hurdles. As Michel Foucault famously noted, "My point is not that everything is bad, but that everything is dangerous, which is not exactly the same as bad" (Foucault 1984, 343)." Understanding what collaboration ${ }_{2}$ can call forth in light of what it has called forth in the past, is one way to be reminded of those dangers.

\section{ACKNOWLEDGMENTS}

I would like to thank Elizabeth Digeser, David R. Mapel, Katherine Goktepe, Julie White, and Bonnie Honig and the three anonymous reviewers for their comments and suggestions on earlier versions of this manuscript. "Google Translate" and "DeepL" aided my translation of a number of articles, but I would like to thank Danielle Crowder for her assistance with German and Cynthia Kaplan for her advice in tracking down Soviet documents.

\section{CONFLICT OF INTEREST}

The author declares no ethical issues or conflicts of interest in this research.

\section{ETHICAL STANDARDS}

The author affirms this research did not involve human subjects.

\section{REFERENCES}

All-Russian Council of Trade Unions. 1926. Red Money: A Statement of the Facts Relating to the Money Raised in Russia during the General Strike and Mining Lock-Out in Britain, trans. Eden \& Cedar Paul. London: Labour Research Department. https:// cdm21047.contentdm.oclc.org/digital/collection/russian/id/6465.

Amulree, William Warrender Mackenzie. 1929. Industrial Arbitration in Great Britain. London: Oxford University Press, Humphrey Milford.

Applebaum, Anne. 2020. "The Collaborators." The Atlantic 326 (1): $48-62$.

Armstrong, John A. 1968. "Collaborationism in World War II: The Integral Nationalist Variant in Eastern Europe." Journal of Modern History 40 (3): 396-410.

Besant, Walter. 1892. "On Literary Collaboration.” New Review 6 (33): 200-09.

Bonitzer, Francine. 1945. "Robert Brasillach 'grande vedette de la collaboration' condamné à mort." L'Aurore : organe de la résistance républicaine, January 20, 1945. https://gallica.bnf.fr/ ark:/12148/bpt6k4125447x/f1.item.

Burrin, Philippe. 1996. France under the Germans: Collaboration and Compromise, trans. Janet Lloyd. New York: The New Press.

"Civilian Life in the Liberated Regimes: A Series of Pictures from Normandy after the Passing of the Germans." 1944. Sphere, July 22, 118.

Cohen, Hillel. 2012. "Society-Military Relations in a State-in-theMaking: Palestinian Security Agencies and the 'Treason Discourse' in the Second Intifada." Armed Forces \& Society 38 (3): $463-85$.

"Collaboration-statue avec piédestal." 1906. In Le Droit d'auteur: organe officiel du Bureau de l'Union internationale pour la protection des oeuvres littéraires et artistiques, November 15 , 141-42. https://gallica.bnf.fr/ark:/12148/bpt6k5497892m/f9.item.r= 1906-11-15. 
“Convention d'armistice.” June 22, 1940. https://mjp.univ-perp.fr/ france/1940armistice.htm.

"Countess Pleads Guilty." 1943. New York Times, October 8.

"Court Theatre." 1872. Athenaeum. April 6, 442.

Czarnota, Adam. 2009. "Lustration, Decommunisation and the Rule of Law." Hague Journal on the Rule of Law 1: 307-36.

David, Roman. 2003. "Lustration Laws in Action: The Motives and Evaluation of Lustration Policy in the Czech Republic and Poland (1989-2001)." Law \& Social Inquiry 28 (2): 387-439.

Deák, István. 2000. "Introduction." In The Politics of Retribution in Europe: World War II and Its Aftermath, eds. István Deák, Jan T. Gross, and Tony Judt, 3-14. Princeton, NJ: Princeton University Press.

Deák, István. 2015. Europe on Trial: The Story of Collaboration, Resistance, and Retribution During World War II. Boulder, CO: Westview Press.

De Ceuster, Koen. 2001. "The Nation Exorcised: The Historiography of Collaboration in South Korea." Korean Studies 25 (2): 207-42.

De Gaulle, Charles. 1944. "What the Enemy Means by Collaboration, London, 20 December 1940." In The Speeches of General De Gaulle, 40-2. London: Oxford University Press.

De Grand, Alexander. 1989. The Italian Left in the Twentieth Century: A History of the Socialist and Communist Parties. Bloomington: Indiana University Press.

"Des Cours de Justice seront chargées de juger les faits de trahison ou de collaboration avec l'ennemi." Combat, September 16, 1944. https://gallica.bnf.fr/ark:/12148/bpt6k4748584g/f2.item.

Dethlefsen, Henrik. 1990. "Denmark and the German Occupation: Cooperation, Negotiation or Collaboration?" Scandinavian Journal of History 15 (1-2): 193-206.

Di Scala, Spenser. 1980. Dilemmas of Italian Socialism: The Politics of Filippo Turati. Amherst: University of Massachusetts Press.

Dostál, Petr F., and Hans Knippenberg. 1992. "Russification of Soviet Nationalities: The Importance of Territorial Autonomy." History of European Ideas 15 (4-6): 631-38.

“Dramatic Collaboration.” 1871. Orchestra, December 8, 155.

"Dramatic Collaboration and Conveyance." 1886. Saturday Review of Politics, Literature, Science and Art, June 26, 881.

Dudai, Ron, and Hillel Cohen. 2007. "Triangle of Betrayal: Collaborators and Transitional Justice in the Israeli-Palestinian Conflict." Journal of Human Rights 6 (1): 37-58.

Ericsson, Kjersti. 2010. "Rape, Love and War-Personal or Political?" Theoretical Criminology 15 (1): 67-82.

Estève, A. 1938. Rapport du Directeur de l'Administration pénitentiaire et des Services de l'Education surveillée à Monsieur Le Garde des Sceaux, Ministre de la justice. Melum Imprimerie administrative. http://data.decalog.net/enap1/Liens/fonds/ F8F15.pdf.

Fisher, Alan W. 1978. The Crimean Tatars. Stanford, CA: Hoover Press.

Foucault, Michel. 1984. "On the Genealogy of Ethics.” In The Foucault Reader, ed. Paul Rabinow, 340-73. New York: Pantheon Books.

Gordon, Bertram M. 1993. "The Morphology of the Collaborator: The French Case." Journal of European Studies 23 (1): 1-25.

Gross, Jan T. 2000. "Themes for a Social History of War Experience and Collaboration." In The Politics of Retribution in Europe, eds. István Deák, Jan T. Gross, and Tony Judt, 15-35. Princeton, NJ: Princeton University Press.

Hickman, John. 2017. "The Occupier's Dilemma: Problem Collaborators." Comparative Strategy 36 (3): 228-40.

Hoffmann, Stanley. 1968. "Collaborationism in France during World War II." The Journal of Modern History 40 (3): 375-95.

Horne, Cynthia M. 2009. "Late Lustration Programmes in Romania and Poland: Supporting or Undermining Democratic Transitions?" Democratization 16 (2): 344-76.

James, Henry. [1892] 2017. Collaboration. Charleston, SC: Éditions Lambda.

Jones, Jeffrey W. 2005. “'Every Family Has Its Freak’: Perceptions of Collaboration in Occupied Soviet Russia, 1943-1948." Slavic Review 64 (4): 747-70.

Kaczorowski, Karol. 2018. "Countering Othering: Social Negotiations of Identity among New Kurdish Migrants in Istanbul." In Rediscovering Kurdistan's Cultures and Identities, ed. Joanna Bocheńska, 151-85. Cham, CH: Palgrave.
Kamm, Frances. 2000. "Responsibility and Collaboration." Philosophy and Public Affairs 28 (3): 169-204.

Kamm, Frances. 2012. "Collaboration with the Enemy: Harming Some to Save Others from the Nazis." In The Moral Target: Aiming at Right Conduct in War and Other Conflicts, 82-113. Oxford: Oxford University Press.

Killingsworth, Matt. 2010. "Lustration and Legitimacy." Global Society 24 (1): 71-90.

Kocher, Matthew Adam, Adria K. Lawrence, and Nuno P. Monteiro. 2018. "Nationalism, Collaboration, and Resistance: France under Nazi Occupation." International Security 43 (2): 117-50.

Labrosse, Diane N. 2008. "'La Dérive Bergery/The Bergery Drift': Gaston Bergery and the Politics of Late Third Republic France and the Early Vichy State." Réflexions Historiques (Historical Reflection) 34 (2): 66-87.

Landolfi, Antonio. 1996. "Birth of Italian Socialism: Reform or Revolution?" In Italian Socialism: Between Politics and History, ed. Spencer M. Di Scala, 9-18. Amherst: University of Massachusetts.

Lemberg, Hans. 1972. "Kollaboration in Europa mit dem Dritten Reich um das Jahr 1941.” In Das Jahr 1941 in der europäischen Politik, ed. Karl Bosl, 143-62. Munich: R. Oldenbourg Verlag.

"Le peuple de France se bat de son côté avec le double courage du désespoir et de l'espoir." 1943. L'Echo d'Alger: journal républicain du matin. June 29. https://gallica.bnf.fr/ark:/12148/bpt6k7587089r/ f1.image.

Lepora, Chiara, and Robert E. Goodin. 2013. On Complicity and Compromise. Oxford: Oxford University Press.

Margalit, Avishai. 2017. On Betrayal. Cambridge, MA: Harvard University Press.

Matthews, Brander. 1890. "The Art and Mystery of Collaboration." Longman's Magazine 16 (92): 157-70.

Michel, Alain. 2011. "Collaboration and Collaborators in France: An Unfinished Debate." In Collaboration with the Nazis: Public Discourse After the Holocaust, ed. Roni Stauber, 169-85. New York: Routledge.

Mihai, Mihaela. 2019. "Understanding Complicity: Memory, Hope and the Imagination." Critical Review of International Social and Political Philosophy 22 (5): 504-22.

Misztal, Barbara A. 1999. "How Not to Deal with the Past: Lustration in Poland." European Journal of Sociology 40 (1): 31-55.

"Mr. Tom Taylor's Plays.” 1871. Athenaeum, June 3, 697.

Munholland, Kim. 1994. "Wartime France: Remembering Vichy." French Historical Studies 18 (3): 801-20.

Murphy, John Thomas. 1934. Preparing for Power: A Critical Study of the History of the British Working-Class Movement. London: Jonathan Cape.

Panzini, Alfredo. 1923. "Collaborazionista" and "Collaborazionismo." Dizionario Moderno: Supplemento ai Dizionari Italiani. Quarta Edzione, 134, 220, 700. Milano: Ulruco Hoepli.

"Partie non Officielle." 1906. Le Droit d'auteur: organe officiel du Bureau de l'Union internationale pour la protection des oeuvres littéraires et artistiques, November 15, 135-37. https://gallica.bnf.fr/ ark:/12148/bpt6k5497892m/f2.item.r=1906-11-15.

Paxton, Robert O. [1972] 2001. Vichy France: Old Guard and New Order 1940-1944. New York: Columbia University Press.

Peteet, Julie. 1999. "Gender and Sexuality: Belonging to the National and Moral Order." In Hermeneutics and Honor: Negotiating Female "Public" Space in Islamic/ate Societies, ed. Asma Afsaruddin, 70-88. Cambridge, MA: Harvard University Press.

“Que signifie la collaboration?" 1941. Notre révolution, February. https://gallica.bnf.fr/ark:/12148/bpt6k877475s?rk=42918;4.

Revkin, Mara. 2018. "Iraq's Harsh Approach to Punishing Islamic State 'Collaborators' Stands to Have Counterproductive Consequences." Lawfare (blog). June 11, 2018. https:// www.lawfareblog.com/iraqs-harsh-approach-punishing-islamicstate-collaborators-stands-have-counterproductive.

Rigby, Andrew. 2001. Justice and Reconciliation: After the Violence. Boulder, CO: Lynne Rienner.

Rings, Werner. 1982. Life with the Enemy: Collaboration and Resistance in Hitler's Europe 1939-1945, trans. J. Maxwell Brownjohn. Garden City, NY: Doubleday \& Company.

Rousso, Henry. 1991. The Vichy Syndrome: History and Memory in France since 1944, trans.Arthur Goldhammer. Cambridge, MA: Harvard University Press. 
Sa'di, Ahmad H. 2005. "The Politics of 'Collaboration': Israel's Control of a National Minority and Indigenous Resistance." Holy Land Studies 4 (2): 7-26.

Sartre, Jean-Paul. [1945] 2008a. "Paris under the Occupation." In The Aftermath of War (Situations III), trans. Chris Turner, 8-40. Oxford: Seagull Books.

Sartre, Jean-Paul. [1945] 2008b. "What is a Collaborator?" In The Aftermath of War (Situations III), trans. Chris Turner, 41-64. Oxford: Seagull Books.

Satkunanathan, Ambika. 2016. "Collaboration, Suspicion and Traitors: An Exploratory Study of Intra-Community Relations in Post-War Northern Sri Lanka." Contemporary South Asia 24 (4): 416-28.

Schaffer, Frederic Charles. 2016. Elucidating Social Science Concepts. New York: Routledge.

Scheck, Raffael. 2010. "The Prisoner of War Question and the Beginnings of Collaboration: The Franco-German Agreement of 16 November 1940." Journal of Contemporary History 45 (2): 364-88.

"Second Letter to the I. L. P." 1926. Lansbury's Labour Weekly 2 (58): 9.

Sennet, Adam, 2021. "Ambiguity." The Stanford Encyclopedia of Philosophy, ed. Edward N. Zalta. Summer edition. https:// plato.stanford.edu/archives/sum2021/entries/ambiguity/.

Simonin, Anne. 2009. "La femme invisible: la collaboratrice politique.” Histoire@Politique 9 (September-December): 1-26.

Smith, Frank. 1924. "Custodians of Capitalism." All Power 3 (28): 8.

Sorensen, Roy. 2018. "Vagueness." The Stanford Encyclopedia of Philosophy, ed. Edward N. Zalta. Summer Edition. https:// plato.stanford.edu/archives/sum2018/entries/vagueness/.
Stauber, Roni. 2011. "Introduction." In Collaboration with the Nazis: Public Discourse after the Holocaust, ed. Roni Stauber, 1-23. New York: Routledge.

Szczerbiak, Aleks. 2016. "Deepening Democratisation? Exploring the Declared Motives for 'Late' Lustration in Poland." East European Politics 32 (4): 426-45.

"The Architect and the Sculptor." 1906. Architects' Magazine 6 (64): 76.

"The Limits of a Surgeon's Liability." 1924. Lancet, January 19.

"The National Minority Conference." 1924. All Power 3 (30): 5.

Treat, John Whittier. 2012. "Choosing to Collaborate: Yi Kwang-su and the Moral Subject in Colonial Korea." The Journal of Asian Studies 71 (1): 81-102.

Virgili, Fabrice. 2002. Shorn Women: Gender and Punishment in Liberation France, trans. John Flower. Oxford: Berg.

Voisin, Vanessa. 2018. "The Soviet Punishment of an All-European Crime, 'Horizontal Collaboration."” In Traitors, Collaborators and Deserters in Contemporary European Politics of Memory, eds. Gelinada Grinchenko and Eleonora Narvselius, 241-64. Camden, UK: Palgave.

Weiss-Wendt, Anton, and Uğur Ümit Üngör. 2011. "Collaboration in Genocide: The Ottoman Empire 1915-1916, the GermanOccupied Baltic 1941-1944, and Rwanda 1994." Holocaust and Genocide Studies 25 (3): 404-37.

"When Parliament Meets." 1925. Lansbury's Labour Weekly 1 (38): 11.

Williams, Brian Glyn. 2002. "The Hidden Ethnic Cleansing of Muslims in the Soviet Union: The Exile and Repatriation of the Crimean Tatars." Journal of Contemporary History 37 (3): 323-47. Wittgenstein, Ludwig. 1958. Philosophical Investigations, trans. G. E. M. Anscombe. New York: Macmillan Company. 